
HORIZONS

\title{
Language Arts
}

Volume 14

Issue 4 July 1974

Article 3

7-1974

\section{Try a Fresh Look at a Trite Subject}

Louis Foley

Babson College

Follow this and additional works at: https://scholarworks.wmich.edu/reading_horizons

Part of the Education Commons

\section{Recommended Citation}

Foley, L. (1974). Try a Fresh Look at a Trite Subject. Reading Horizons: A Journal of Literacy and Language Arts, 14 (4). Retrieved from https://scholarworks.wmich.edu/reading_horizons/vol14/iss4/3

This Article is brought to you for free and open access by the Special Education and Literacy Studies at ScholarWorks at WMU. It has been accepted for inclusion in Reading Horizons: A Journal of Literacy and Language Arts by an authorized editor of ScholarWorks at WMU. For more information, please contact wmuscholarworks@wmich.edu.

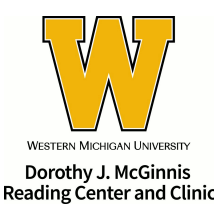




\title{
TRY A FRESH LOOK AT A TRITE SUBJECT*
}

\author{
Louis Foley \\ PROFESSOR EMERITUS, BABSON COLLEGE
}

Recently, a distinguished literary critic, speaking of the "rotten writer," said that such a person is convinced that all rules of grammar are obsolete, "now that the split infinitive has earned acceptance."1 It is not altogether clear whether the latter part of that statement is merely intended to represent the opinion of the "rotten writer" or whether the critic himself accepts it as a foregone conclusion. In either case the wording is rather captious and unrealistic. How can the split infinitive be said to have "earned acceptance"? It has no earning power. It is not an active entity in itself, not a cause of anything but only a result, a byproduct of something else.

A Guide to Writing Style and Usage published by the American Oil Company for use by company communicators starts off its introduction with the remark:

It's true that some people worship alleged rules of syntax as they'd worship their mother's memory: 'Never split an infinitive; never end a sentence with a preposition.' (Those are both nonsense, by the way.)

Here, as frequently happens, we see lumped together two quite distinct things which have seemed to stand in many people's minds as archetypes of "bad grammar." Actually they are not matters of structural grammar at all but simply questions of word-order. They are related to grammar only because grammatical construction is what logically determines word-order. Let us, however, put aside the question of "final prepositions" (which one might claim hardly to have existed anyhow in the true sense) and confine ourselves to a little examination of the famous split infinitive.

Apparently the Guide from which we have just quoted represents the "in" attitude at the present time: any "alleged rule" against splitting infinitives is to be regarded as merely an old-fashioned cranky notion which enlightened people nowadays look upon as "nonsense." The interesting thing about it is that both the older textbooks, which forbade splitting, and the more modern ones which

\footnotetext{
*This article was first published in the Journal of Technical Writing and Communication, Vol. 2 (4), pp. 295-305, October, 1972. Permission for publishing it in Reading Horizons has been given by the Editor of the Journal of Technical Writing and Communication.
} 


\section{$172-r h$}

either seek to justify it or treat it as of no importance, have alike missed the point, on one side about as completely as on the other. Indeed it is amazing, in all the recurring mention of the matter over a period of years, how arguers on both sides of the question have steadfastly refused to look into it enough to see what it is really "all about."

Now, whatever one may think about the importance of a split infinitive in itself, or of avoiding it, this question does offer a particularly good approach for looking into the whole affair of proper wordorder. And that, far from being nonsense, is in general very sensible and practical. In ordinary simple circumstances anyone having the feeling of the language takes care of it without effort as by instinct. When ideas become more complicated, without having a sense of the basic principles one may become entangled and make expression quite needlessly awkward.

\section{PROPER WORD-ORDER}

The basic principle of proper word-order is utterly reasonable. It is simply that the words most closely related in grammar-that is to say in the thought-pattern-should be closest together in the arrangement of word-order. This is not a matter of "rules" invented by grammarians; it is fundamental in the coherent structure of language. Sometimes, however, certain rules which have been traditionally taught have tended to obscure rather than illuminate this basic principle. Parsing and diagraming of sentences-instructional devices which are certainly not without value as far as they go- often fail to bring out real relationships.

What brings the question of split infinitives into the picture is the handling of adverbs. In studying grammar everyone learns that adverbs are modifiers of verbs (or of adjectives or other adverbs). This is only a partial truth. Often an adverb or adverbial phrase really modifies a whole sentence, as it does commonly when it comes at the beginning with something that applies to the entire statement. In the case of transitive verbs, what the adverb modifies is not simply the "verb" but the verb plus its object, without which the action cannot be conceived. In such case the normal position for an adverb is after the unified phrase formed by the verb and its object. This is true because the adverb can have no meaning until we know to what it applies.

When, as most often happens, the verb has a simple short object, the adverb falls naturally after the tightly-joined phrase of verb-plusobject:

He does his work carefully. 


\section{$r h-173$}

With a longer object, the adverb slips in ahead of it:

He does carefully all the work that is assigned to him.

To make it wait until after the object would not only be too awkward a separation but might be ambiguous: "He does all the work that is assigned to him carefully" would sound as if "carefully" applied to the manner of assignment.

With these clear principles in mind, looking in to the evolution of sentence-structure within modern times, we can see the question of split infinitives in proper perspective. The split infinitive is essentially a nineteenth- and especially a twentieth-century phenomenon, and it is not hard to see just how it came about. We can understand it as an off-hand reaction against a peculiar twist of word-order which surely contributed as much as any one feature of "style" to give an air of stiffness and impersonality to much old-fashioned writing. This appears in various expressions traditionally preserved by the importance of their context, as in The Book of Common Prayer: ". . . we ought at all times humbly to acknowledge our sins ..."; "yet ought we chiefly so to do when we assemble ..." Again in the first amendment to the Constitution: "The right of the people peaceably to assemble..."

\section{EXAMPLES OF FORMAL STYLE}

Down to the present day, this archaic fashion is still followed occasionally in trying to be "formal" or literary. In his 1966 State of the Union message the President said he would ask Congress to consider measures which would enable us "effectively to deal with strikes which threaten irreparable damage to the national interest." In a review of the Guerilla Handbook by Paul Mus, 1967, we read: "Their quickness and clarity of mind led the Vietnamese unreservedly to grasp and embrace the profound and masterful survey of the ancient world structure . . of their Chinese neighbors." A columnist referred to the Glassboro meeting between Premier Kosygin and President Johnson as "only a beginning which could do no more than enable the two gingerly to touch the fringes of the vital and wide-ranging matters they need to explore in depth."2 A newspaper editorial says that many experts hold that "it is impossible adequately to define and to prove what intent to cite to riot means."3 A report from Russia informed us that diplomats "were beginning seriously to worry about Moscow's psychological and political atmosphere." Referring to hunting in the mountains, a writer lists "the conditions which must prevail if one is successfully to hunt deer in the deep snow." An editor speaks of "the Anglo-French agreement 


\section{$174-r h$}

jointly to build a swing-wing jet fighter aircraft." These examples will be recognized as typical.

After split infinitives began to appear often enough to be noticeable, that quaintly stilted word-order was earnestly presented as the "correct" form to use instead. Thus the matter is handled in a generally excellent handbook published in 1922 and widely used for years in college classes:

Wrong: In order to adequately present my claim, I ask for the privilege of an interview.

Right: In order adequately to present my claim, I ask for the privilege of an interview. 4

Both versions miss the point. The natural and logical word-order would be: "In order to present my claim adequately . . ." What adequately modifies is the unified phrase to present my claim. Moreover, falling at the end of the clause it gets its proper emphasis as the important word without which we can hardly imagine the sentence being used at all.

The present widespread attitude of nonchalant refusal to face the realities of idiomatic word-order must have been considerably encouraged by a statement repeated time after time in successive editions of Webster's Collegiate Dictionary: "The splitting has been widely objected to, but it sometimes is desirable or necessary, especially to avert ambiguity." (In passing, we may notice the inept word-order of the statement itself; sometimes belongs with the adjectives it modifies: sometimes desirable or necessary.) This pontifical declaration is entirely arbitrary; though rarely enough, a split infinitive may cause ambiguity, but it is never necessary to avoid that.

This curious notion about "ambiguity" sounds as if it might be due to the influence of Professor George O. Curme of Northwestern University, "noted champion of the split infinitive," who back in the 1930's "sold" the Modern Language Association on his views. His supposedly clinching example to prove that a split infinitive may be "quite necessary to convey shades of meaning" was a comparison of two sentences:

He failed completely to understand the question.

and

He failed to completely understand the question.

To him it seemed "obvious that the meaning of the second expression is entirely different from the first, and ... the split form is needed to convey the impression of partial understanding."

The fact is that neither of these expressions is really good English. As written, the first may be ambiguous. If spoken, with a slight pause 
after "completely," the adverb would seem to modify failed: he failed completely. Otherwise, it looks like the old stiff word-order, avoiding a split infinitive at any cost but not seeing why. Whereas there is a well-worn idiomatic path to each of the two meanings:

He completely failed to understand the question.

or

He failed to understand the question completely.

In the second, what "completely" modifies is not "to understand" but to understand the question. Actually the example has somewhat the air of a textbook specimen artificially devised to demonstrate something. One might be more likely to say "to understand the complete question" or "the question as a whole."

\section{ELEMENTS OUT OF ORDER}

In the vast majority of all split infinitives that may be found anywhere, it is not hard to see that the element which does the splitting belongs elsewhere for reasons of its own, not simply to preserve the integrity of the infinitive.

You have no idea what it means to suddenly have the rug jerked out from under you ..."5 (to have the rug suddenly jerked)

... Enough information should be released to at least cast some doubt upon the validity . .."6 (at least some doubt, "at least" modifying some)

Canadians ... may be one of the first peoples to legally guarantee all citizens the right to a decent environment.7 (to guarantee to all citizens the legal right)

We have one-half acre of floor space on which to partially exhibit our collection of more than three thousand Oriental Rugs.8 (to exhibit part of our collection)

.. . The Board of Directors voted unanimously to recommend their adoption to better enable the CEA to speak and act on problems confronting our profession.9 (to enable the CEA to speak and act better)

A spokesman for Toyota says that the dock strike is making it difficult at this point to fully determine the effectiveness of the economic program.10 (to determine the full effectiveness)

The scientist's purpose is to consciously avoid multiple meaning, emotional attitudes, and a plurality of implications.11 (conscious purpose is to avoid)

... The Federal Reserve Board was forced to drastically raise money rates . . .12 (to raise money rates drastically)

The major financial requirement for comfortable retirement is, naturally, a dependable income, sizable enough to reasonably maintain a living standard consistent with that to which one is accustomed.13 (a living standard reasonably consistent) 
It has not been possible so far to conclusively prove this theory . . .14 (to prove this theory conclusively)

The loan shark may even seek to publicly embarrass his client.15 (to embarrass his client publicly; final emphasis belongs with publicly; he embarrasses clients privately all the time)

Galbraith's solution is to promptly restructure our universities - and Harvard more promptly than any other . . .16 (to restructure our universities promptly, and Harvard more promptly)

Every now and then in a sentence we may have more than one element which should logically be next to another to which both are closely related. Easily enough, however, we can always find an arrangement which makes only a short separation instead of a long one. Missing this easy adjustment is what causes a large share of characteristic split infinitives.

... We cheat ourselves and demean the heroism of our astronauts . $\alpha$. if we fail fully to grasp the fantastic feat they are attempting. 17 (to grasp fully-apparent evasion of split infinitive put "fully" as if it modified fail. A short object would have come between: to grasp it fully)

When he passed examinations, his teachers are reported regretfully to have put it dozen to 'flair' rather than industry. 18 (to have put it down regretfully-unintelligent avoidance of infinitive-splitting makes "regretfully" look as if it modified reported)

Under Greek law ... it was a religious crime to forcibly remove anyone who sought haven.19 (to remove forcibly)

They hope to convince the jurors that . . he did not have the capacity to maturely and rationally plan a deliberated, premeditated first-degree murder.20 (to plan maturely and rationally)

\section{FAULTY SENTENCE STRUCTURE}

We have seen how the textbook treatment of the split infinitive has been to take it as a fault per se to be "corrected." This has regularly been an affair of treating a symptom without detecting the underlying malaise. For it is safe to say that a split infinitive regularly appears as a symptom of something wrong somewhere-not always the same thing. Most often it is merely a case of awkward word-order, but it may result from fundamentally faulty sentence-structure, or not paying attention to what words are supposed to mean.

... He made no prior U.S. commitment to actually enter diplomatic relations.21 (to enter actual diplomatic relations)

The pattern has been to always credit the civilian bosses with any successes and to blame the military for any failures. 22 (pattern has always been) 
I suggest that . . you urge your readers to actually look at the words in our report, not at your garbled distortions. 23 (to look at the actual words)

Keep a consistent eye on ads to really find the bargains. 24 (to find the real bargains)

Enough people voted for him to almost make him president.25 (almost enough people)

... In order to successfully prolong the delights of the controversy he must find some means of reducing the great odds against him.26 (to succeed in prolonging)

As amusing an example as any is one of the earliest split infinitives to be found in English literature, a line from Burns' Cotter's Saturday Night (1786):

Who dared to nobly stem tyrannic pride.

Can anyone imagine stemming as being done "nobly"? Nobly belongs with dared, for it is the daring that is to be considered noble. The poet could just as well have written: "Who nobly dared ..." Indeed he might have done still better, for the noble courage was rather in the resolution to oppose "tyrannic pride," when it was by no means certain that he could succeed in "stemming" it. The line could have been:

Who nobly dared oppose tyrannic pride.

Among the innumerable textbook writers who have undertaken to deal with the subject, we may single out one who approaches it with an unusual effort to be fair-minded. "You have probably been taught," he says, "that the split infinitive is a particularly bad fault. You should try to avoid the construction, but not at the expense of reducing clarity or sounding forced and artificial . . Nowadays most authorities take a moderate view of the split infunitive."

He shows by a number of good examples that a person "can of ten avoid the split infinitive with no difficulty," and in each case his correction of the word-order obviously improves the sentence from any point of view. One example, however, he cites as seeming to him exceptional, "a perfectly clear sentence that contains a split infinitive":

A study must be included to properly integrate the computer with the other main components of the control system.

He then tries moving "the splitting word-properly-to any of several different places."

A study must be included properly to integrate the computer... This he sees at once as ambiguous, for "now properly might modify included." Here we notice the old twisted word-order which apparently led to split infinitives as a pis aller. Likewise he rejects: 


\section{$178-r h$}

A study must be included to integrate properly the computer . . . as "strange and foreign, because it simply is not English idiom." Obviously unacceptable also is the holding of properly for the end: $A$ study must be included to integrate the computer with the other main components of the control system properly.

Inevitably, then, as "the best of the four possible revisions," he arrives at the well-established manner of avoiding awkward separation which we have already seen in various quotations:

$A$ study must be included to integrate the computer properly with the other main components. . .

Yet strangely enough he feels that "it still lacks the clarity and the vigor of the original sentence with the split infinitive." 27

Just where the extra "clarity and vigor" come in is not easy to see. Actually it looks as if momentary concentration upon the problem of word-order had tended to cloud perception of implications in the meaning of the words themselves. If the computer can be truly said to be integrated, then the presumed purpose is accomplished. For something to be not "properly integrated" would seem to imply that it ought not to be integrated at all. Seeking to integrate it with the system would just not be the proper (suitable or appropriate) thing to do. So we need not bother about finding a place for properly; the sentence does not need it anyhow.

\section{REARRANGEMENT OF ELEMENTS}

In the great majority of all split infinitives one is likely to come upon, it is easy enough to show that the element which does the splitting should naturally and logically be in another place instead of where it is. We need not take absolutely for granted, however, that it belongs somewhere in the sentence. It may have slipped in through carelessness as to honest meanings of words. A striking example of this sort appears in a pronouncement by an educator that "inability to satisfactorily measure up to the expectations and demands of his parents or teachers" may cause a child to have excessive worry and fear.28 Now what can "measure up" mean unless it is to be satisfactory? The idea would be completely expressed by saying "to satisfy the expectations..."

We have not considered the peculiar anomaly in English, in contrast to other languages, that an infinitive should ever be thought of as comprising two separable words. Logically the particle to which marks its mood is as truly a part of the verb-form as are suffixes which indicate tense, or changes of form which show the subjunctive or the third person singular. Yet, we cannot write it as one word, as we do with innumerable compounds no more truly unified if as much so. 
We are inescapably saddled with results of confusion of centuries ago which gives the infinitive an appearance of a prepositional phrase when it is nothing of the sort.

Perhaps there is a lesson to be drawn as to the futility of merely negative "rules." The split infinitive is not something to be anxiously avoided. If we just do the positive thing of putting words where they naturally belong in the pattern of a sentence, with respect for their rational meanings, there is little likelihood that any split infinitive will ever occur.

\section{REFERENCES}

1. Melvin Maddocks, Christian Science Monitor, December 17, 1971.

2. Christian Science Monitor, June 24, 1967.

3. Ibid.

4. George B. Woods, A College Handbook of Writing, Doubleday, Page \& Co., 1922, p. 71.

5. Erle Stanley Gardner, The Case of the Beautiful Beggar, Pocket Books No. 50376, p. 204.

6. Christian Science Monitor, November 13, 1967.

7. Ibid, December 3, 1969.

8. Ibid, April 2, 1970.

9. College English Association notice to members, 1971.

10. Christian Science Monitor, November 20, 1971.

11. Literature in Critical Perspectives, Rutgers, Camden, N.J., March, 1968.

12. Investment letter, April 10, 1967.

13. Business report, March 4, 1968.

14. Christian Science Monitor, June 16, 1969.

15. Ibid.

16. Al Capp, speech at Franklin Pierce College, April 27, 1969.

17. San Francisco Examiner, July 18, 1969.

18. Christian Science Monitor, June 24, 1969.

19. The New York Times, June 2, 1968.

20. Ibid., March 2, 1969.

21. Christian Science Monitor, April 24, 1969.

22. Senator Margaret Chase Smith, quoted in Boston Herald Traveler, July 10, 1969.

23. Chicago Tribune, July 14, 1969. 
$180-r h$

24. Christian Science Monitor, March 5, 1970.

25. Ibid., June 28, 1969.

26. O. Henry, "The Reformation of Calliope," in Heart of the West.

27. Joseph N. Ulman, Jr., Technical Reporting, Henry Holt and Company, 1952, pp. 106-107.

28. Journal of the N.E.A., February 1931, p. 50. 